\title{
Paraneoplastic Diseases of the Central Nervous System
}

\section{[version 1; peer review: 2 approved]}

\author{
Jonathan Galli (D1,2, John Greenlee (D)1
}

${ }^{1}$ Department of Neurology, University of Utah, Salt Lake City, UT, 84108, USA

22. George E. Wahlen Department of Veterans Affairs Medical Center, Salt Lake City, UT, 84148, USA

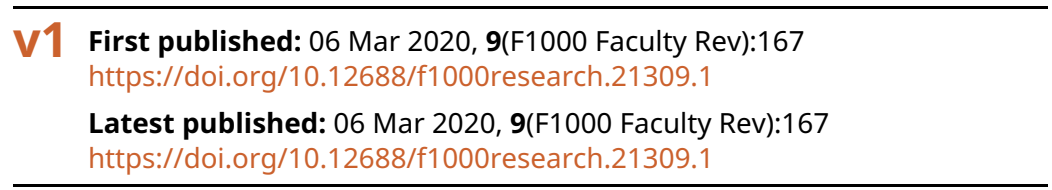

\section{Abstract}

Paraneoplastic neurological syndromes are nonmetastatic complications of malignancy secondary to immune-mediated neuronal dysfunction or death. Pathogenesis may occur from cell surface binding of antineuronal antibodies leading to dysfunction of the target protein, or from antibodies binding against intracellular antigens which ultimately leads to cell death. There are several classical neurological paraneoplastic phenotypes including subacute cerebellar degeneration, limbic encephalitis, encephalomyelitis, and dorsal sensory neuropathy. The patient's clinical presentations may be suggestive to the treating clinician as to the specific underlying paraneoplastic antibody. Specific antibodies often correlate with the specific underlying tumor type, and malignancy screening is essential in all patients with paraneoplastic neurological disease. Prompt initiation of immunotherapy is essential in the treatment of patients with paraneoplastic neurological disease, often more effective in cell surface antibodies in comparison to intracellular antibodies, as is removal of the underlying tumor.

\section{Keywords}

neurological, paraneoplastic, antibody-mediated, immunotherapy

\section{Open Peer Review}

Approval Status

1 2

version 1

06 Mar 2020

Faculty Reviews are review articles written by the prestigious Members of Faculty Opinions. The articles are commissioned and peer reviewed before publication to ensure that the final, published version is comprehensive and accessible. The reviewers who approved the final version are listed with their names and affiliations.

1. Francesc Graus, University of Barcelona,

Barcelona, Spain

2. Jerome Honnorat, Université de Lyon, Université Claude Bernard Lyon, Lyon, France Any comments on the article can be found at the end of the article. 
Corresponding author: John Greenlee (john.greenlee@hsc.utah.edu)

Author roles: Galli J: Conceptualization, Writing - Original Draft Preparation, Writing - Review \& Editing; Greenlee J: Conceptualization, Writing - Original Draft Preparation, Writing - Review \& Editing

Competing interests: No competing interests were disclosed.

Grant information: This research was supported by a Merit Review award from the US Department of Veterans Affairs (JEG). The funders had no role in study design, data collection and analysis, decision to publish, or preparation of the manuscript.

Copyright: $\odot 2020$ Galli J and Greenlee J. This is an open access article distributed under the terms of the Creative Commons Attribution License, which permits unrestricted use, distribution, and reproduction in any medium, provided the original work is properly cited.

How to cite this article: Galli J and Greenlee J. Paraneoplastic Diseases of the Central Nervous System [version 1; peer review: 2 approved] F1000Research 2020, 9(F1000 Faculty Rev):167 https://doi.org/10.12688/f1000research.21309.1

First published: 06 Mar 2020, 9(F1000 Faculty Rev):167 https://doi.org/10.12688/f1000research.21309.1 


\section{Introduction}

Paraneoplastic neurological syndromes are non-metastatic complications of systemic malignancy, in which clinical syndromes are the result of immune-mediated neuronal dysfunction or death. The syndromes may have their onset as long as five years prior to detection of the associated malignancy, during treatment, or (less often) when the underlying malignancy is in remission. The syndromes occur when the underlying neoplasm expresses proteins that are cross-reactive with neuronal antigens ${ }^{1-4}$. Paraneoplastic neurological syndromes are thus among the few autoimmune conditions in which the immune targets that initiate the disease are known. In this review, we concentrate predominantly on paraneoplastic neurological syndromes affecting the central nervous system (CNS) or sensory ganglia; syndromes affecting the myoneuronal junction or peripheral nerves will not be discussed. The article will discuss current concepts of pathogenesis, clinical features of the major paraneoplastic syndromes, and approaches to treatment.

\section{Pathogenesis}

That paraneoplastic neurological injury could have an autoimmune basis was suggested by Wilkinson and Zebrowski in the $1960 \mathrm{~s}^{5}$ and Trotter et al. in the 1970s $\mathrm{s}^{6}$. A definitive association of autoimmunity in paraneoplastic neurological disease came through work by Greenlee and Brashear ${ }^{7}$ and Jaeckle et al. ${ }^{8}$, who demonstrated antibodies to cerebellar Purkinje cells in patients with paraneoplastic cerebellar degeneration. Over the ensuing years, many other patterns of antibody response have been associated with neurological disease in the presence of other systemic cancers (Table 1 and Table 2), and it is now recognized that paraneoplastic neurological syndromes may be accompanied by two separate patterns of immune response: syndromes in which the immune response is directed against neuronal receptors or other cell membrane antigens and syndromes in which immunoreactivity is directed against intracellular neuronal proteins. The former group of syndromes are characterized by neuronal dysfunction, may or may not be associated with underlying neoplasia, and are frequently amenable to treatment. Syndromes in the latter group-those in which the immune response targets intracellular antigensare almost always found in the presence of cancer and are characterized by neuronal death. Neurological deficits in these conditions, once intrinsic neuronal reserve has been exhausted, are irreversible.

\section{The role of tumor antigens in the pathogenesis of paraneoplastic neurological disease}

That tumors may harbor antigens cross-reactive with neuronal proteins was demonstrated by early investigators ${ }^{1-3}$, and subsequent work demonstrated that these antigens may be detected not only in patients with paraneoplastic neurological disease but also in cancer patients who remain neurologically normal ${ }^{9,10}$. More recent studies of ovarian tumors from patients with paraneoplastic cerebellar degeneration and anti-Yo antibodies, the major antibodies associated with the condition, have demonstrated that, although ovarian tumors from anti-Yopositive and anti-Yo-negative patients were histologically similar, ovarian tumors from anti-Yo-positive patients differ from tumors from patients without anti-Yo antibodies by high rates of genetic alterations in key CDR and, to a greater extent, CDR2L (CDR2-like) Yo antigens and by intense tumor infiltration by plasma cells and cytotoxic $\mathrm{CD}^{+}$lymphocytes ${ }^{11,12}$. Recent studies of ovarian teratomas from patients with anti- $N$-methylD-aspartate receptor (anti-NMDAR) encephalitis have shown

Table 1. Major paraneoplastic antineuronal antibodies reactive with neuronal membrane antigens.

\begin{tabular}{|c|c|c|c|c|}
\hline Antibody & $\begin{array}{l}\text { Common neurological } \\
\text { phenotypes }\end{array}$ & $\begin{array}{l}\text { Common associated } \\
\text { malignancies }\end{array}$ & $\begin{array}{l}\text { Frequency of } \\
\text { underlying } \\
\text { malignancy }\end{array}$ & $\begin{array}{l}\text { Response to } \\
\text { treatment }^{\text {a }}\end{array}$ \\
\hline Anti-AMPAR & Limbic encephalitis & $\begin{array}{l}\text { Breast } \\
\text { Lung } \\
\text { Thymus }\end{array}$ & Common & $\begin{array}{l}\text { Good in many } \\
\text { but not all } \\
\text { patients }\end{array}$ \\
\hline $\begin{array}{l}\text { Anti-LGl1/Anti- } \\
\text { CASPR2 }\end{array}$ & $\begin{array}{l}\text { Limbic encephalitis } \\
\text { Faciobrachial dystonic } \\
\text { seizures } \\
\text { Morvan's syndrome }\end{array}$ & $\begin{array}{l}\text { Thymoma (especially in patients } \\
\text { positive for both antibodies) } \\
\text { Other neoplasms (rare) }\end{array}$ & & Usually poor \\
\hline Anti-GABAbR & $\begin{array}{l}\text { Limbic encephalitis, } \\
\text { status epilepticus }\end{array}$ & Small-cell lung cancer & Common & Poor \\
\hline Anti-mGluR1 & Cerebellar degeneration & Hodgkin's disease & Common & Good \\
\hline Anti-mGlur2 & Cerebellar degeneration & $\begin{array}{l}\text { Small-cell cancer; alveolar } \\
\text { rhabdomyosarcoma }\end{array}$ & Common & Variable \\
\hline Anti-mGluR5 & Limbic encephalitis & Hodgkin's disease & Common & Good \\
\hline Anti-VGKC & $\begin{array}{l}\text { Cerebellar degeneration } \\
\text { (Lambert-Eaton } \\
\text { myasthenic syndrome) }\end{array}$ & Small-cell lung cancer & Common & $\begin{array}{l}\text { Good in some } \\
\text { patients }\end{array}$ \\
\hline
\end{tabular}

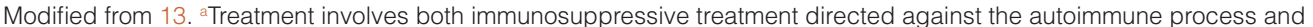
treatment of the underlying malignancy. 


\begin{tabular}{|c|c|c|c|c|}
\hline Antibody & $\begin{array}{l}\text { Common neurological } \\
\text { phenotypes }\end{array}$ & $\begin{array}{l}\text { Common associated } \\
\text { malignancies }\end{array}$ & $\begin{array}{l}\text { Frequency of } \\
\text { underlying } \\
\text { malignancy }\end{array}$ & $\begin{array}{l}\text { Response to } \\
\text { treatment }^{\mathrm{a}}\end{array}$ \\
\hline Anti-CRMP5 & $\begin{array}{l}\text { Optic neuritis } \\
\text { Cerebellar degeneration } \\
\text { Encephalomyelitis }\end{array}$ & $\begin{array}{l}\text { Small-cell lung cancer } \\
\text { Breast carcinoma }\end{array}$ & Common & Poor \\
\hline Anti-GAD65 & $\begin{array}{l}\text { Stiff person syndrome } \\
\text { Limbic encephalitis } \\
\text { Cerebellar ataxia }\end{array}$ & $\begin{array}{l}\text { Thymoma } \\
\text { Renal cell carcinoma }\end{array}$ & Uncommon & $\begin{array}{l}\text { Good in stiff } \\
\text { person syndrome; } \\
\text { otherwise poor }\end{array}$ \\
\hline $\begin{array}{l}\text { Anti-Hu } \\
\text { (ANNA-1) }\end{array}$ & $\begin{array}{l}\text { Limbic encephalitis, } \\
\text { encephalomyelitis, dorsal } \\
\text { sensory neuropathy }\end{array}$ & $\begin{array}{l}\text { Small-cell lung cancer } \\
\text { Neuroendocrine tumors } \\
\text { Retinoblastoma (infants) }\end{array}$ & Almost invariable & Poor \\
\hline Anti-Ma1 & $\begin{array}{l}\text { Limbic or brain-stem } \\
\text { encephalitis }\end{array}$ & $\begin{array}{l}\text { Non-small-cell lung } \\
\text { cancer; other }\end{array}$ & Almost invariable & Poor \\
\hline Anti-Ma2 & $\begin{array}{l}\text { Limbic or brain-stem } \\
\text { encephalitis }\end{array}$ & $\begin{array}{l}\text { Testicular or other germ } \\
\text { cell tumors } \\
\text { Non-small-cell lung } \\
\text { cancer }\end{array}$ & Almost invariable & $\begin{array}{l}\text { Good if testicular } \\
\text { neoplasm detected } \\
\text { and treated }\end{array}$ \\
\hline $\begin{array}{l}\text { Anti-Ri } \\
\text { (ANNA-2) }\end{array}$ & $\begin{array}{l}\text { Cerebellar degeneration, } \\
\text { opsoclonus myoclonus, } \\
\text { brain-stem encephalitis }\end{array}$ & $\begin{array}{l}\text { Breast } \\
\text { Small-cell lung cancer }\end{array}$ & Almost invariable & $\begin{array}{l}\text { Stabilization in } \\
\text { some but not all } \\
\text { patients }\end{array}$ \\
\hline Anti-Tr & Cerebellar degeneration & Hodgkin's disease & Almost invariable & Poor \\
\hline $\begin{array}{l}\text { Anti-Yo } \\
\text { (PCA-1) }\end{array}$ & Cerebellar degeneration & $\begin{array}{l}\text { Ovary, uterus, adnexa } \\
\text { Breast }\end{array}$ & Almost invariable & Poor \\
\hline
\end{tabular}

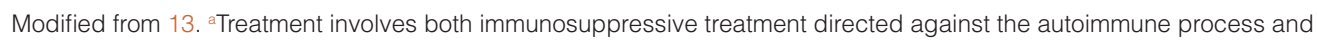
treatment of the underlying malignancy.

that teratomas from NMDAR encephalitis are much more likely to contain predominantly glial elements suggestive of neuroglial tumors than those without encephalitis and may also have extensive infiltrates of $\mathrm{T}$ and $\mathrm{B}$ cells as well as $\operatorname{IgG}$ and $\operatorname{IgA}$ deposits in close contact with the neuroglial components of the teratomas ${ }^{14}$. All of these more recent data suggest that tumors from patients with paraneoplastic neurological syndromes may have unique properties capable of breaking immune tolerance and triggering a vigorous B- and T-cell response.

\section{Syndromes associated with antibodies to cell membrane antigens}

In this group of conditions, neuronal injury occurs when antibodies bind to and impair the function of neuronal membrane proteins. The best studied of these conditions is anti-NMDAR encephalitis. This condition was initially described in women with ovarian teratomas but may also occur in the absence of underlying neoplasia and can also affect males. In anti-NMDAR encephalitis, antibody binding to the NMDAR results in receptor cross-linking internalization and in depletion of receptors on the cell surface ${ }^{15-17}$. Similar immunological mechanisms are thought to be shared by conditions associated with antibodies to the $\alpha$-amino-3-hydroxy-5-methyl-4isoxazolepropionic acid (AMPA) receptor and many but not all other antibodies to cell surface antigens ${ }^{18-20}$. An important point in these conditions is that reconstitution of neuronal surface receptors may occur slowly and may require protracted therapy over weeks to months ${ }^{21}$.

\section{Syndromes associated with an immune response to intracellular neuronal proteins}

The mechanisms of neuronal injury in this group of conditions have remained controversial and understanding of the role of these antibodies in disease pathogenesis has been greatly hindered by the lack of an animal model. Early attempts to produce paraneoplastic disease in animals by passive transfer of antibodies or immunization with antigen or nucleic acids were uniformly unsuccessful ${ }^{22-25}$, leading many investigators to conclude that the associated antibodies were simply markers for underlying neoplasia. T lymphocyte response in patients with antibodies to internal cellular proteins (for example, Yo and $\mathrm{Hu}$ ) has been repeatedly demonstrated: infiltrates of cytotoxic $\left(\mathrm{CD}^{+}\right)$lymphocytes have been detected in brains of patients with encephalomyelitis and anti-Hu antibody ${ }^{26}$ and in cerebrospinal fluid (CSF) of a patient with anti-Yo-associated paraneoplastic cerebellar degeneration ${ }^{27}$. Cross-reactive T-cell receptors have been reported in brain and tumor tissue from a patient with paraneoplastic encephalomyelitis ${ }^{28}$. Interestingly, however, Sillevis Smitt et al. failed to detect cytotoxic T lymphocytes in serum or CSF of patients with anti-Hu antibodies and paraneoplastic neurological disease ${ }^{29-31}$. We are aware of only one attempt to cause neuronal death using $\mathrm{T}$ cells sensitized 
to paraneoplastic antigens in an animal model. That study, by Pellkofer et al., though producing a predominantly meningitis response, did not duplicate paraneoplastic neurological disease $^{32}$.

The role of antibodies in causing neuronal injury is controversial. Neurons have traditionally been considered to exclude immunoglobulins ( $\operatorname{IgG})$; for this reason, it has been thought unlikely that antibodies could reach their intracellular antigenic targets. However, the ability of neurons in living animals to incorporate immunoglobulins was demonstrated many years ago by Fabian and Petroff ${ }^{33}$ and was suggested by Griffin et al. ${ }^{34}$ in experimental Sindbis virus infection. Neuronal uptake of paraneoplastic and other IgGs was documented by Graus et al. ${ }^{23}$ in studies using intraventricular infusion of $\mathrm{IgG}$ in guinea pigs and by Greenlee et al..$^{35}$ following blood-brain barrier disruption after intraperitoneal injection of anti-Yo IgG. Both our laboratory and that of Vedeler et al. have demonstrated that anti-Yo IgG can be taken up by Purkinje cells in rat cerebellar slice cultures and can cause cell death ${ }^{36-39}$; and anti-Hu IgG, associated with encephalomyelitis in the setting of small-cell lung cancer, has been shown to produce neuronal death in dispersed cultures of cerebellar neurons and of multiple neuronal populations in slice cultures of rat brains ${ }^{40,41}$. These studies have not been extended to living animals, however, and a major challenge in developing such a model has been the difficulty of achieving antibody penetration across the blood-brain barrier into brain over prolonged periods of time. Study of a third possible mechanism of injury-that paraneoplastic neuronal injury involves both $\mathrm{T}$ and $\mathrm{B}$ cells-must also await the development of an animal model.

\section{Clinical presentations of major paraneoplastic neurological syndromes}

Anti-NMDAR encephalitis

Anti-NMDAR encephalitis was initially described in women with ovarian teratomas but can occur in patients with other (predominantly germ cell) neoplasms and also in both females and males without neoplasia ${ }^{4,21}$. It can also occur as apparent clinical relapse in patients recovering from herpes simplex virus encephalitis $^{42}$. Anti-NMDAR encephalitis remains by far the most commonly diagnosed disorder associated with antineuronal autoantibodies and its frequency surpasses those of individual viral encephalitides ${ }^{43}$. The disorder is complex, and a range of symptoms suggests the involvement of multiple brain regions and can include cognitive and memory deficits, refractory seizures (including status epilepticus), significant dysautonomia, limbic symptoms, psychiatric disturbances (including agitation paranoia), catatonia, movement disorders, seizures, autonomic dysfunction, hypoventilation which may require artificial ventilation, and coma ${ }^{21,44-46}$. Patients often present initially with behavioral changes, including insomnia, agitation, paranoia, and hallucinations, developing over several weeks to months ${ }^{47}$. Magnetic resonance imaging (MRI) often demonstrates T2 hyperintensity within the mesial temporal lobes ${ }^{48}$. An electroencephalogram (EEG) may demonstrate temporal slowing or epileptogenic activity ${ }^{49}$. Very few cases of NMDAR encephalitis have come to autopsy but these suggest some degree of neuronal loss and extensive brain infiltration by lymphoid cells, in particular by B cells and plasma cells. The disorder is often responsive to immunomodulatory therapy, including steroids, plasma exchange, intravenous immunoglobulin (IVIG), and rituximab. Recovery, however, may require prolonged treatment over weeks to months, and some patients can relapse.

Autoimmune encephalitis with antibodies to the voltagegated potassium channel complex: LGI1 and CASPR2

Autoimmune encephalitis associated with antibodies to LGI1 and CASPR2 is only infrequently associated with underlying malignancy; however, in patients positive for both antibodies, the likelihood of cancer approaches $44 \%$ and thymomas constitute the majority of these cases $^{50}$. Anti-LGI1 encephalitis is typically characterized by faciobrachial dystonic episodes that may or may not have an ictal EEG accompaniment. Anti-CASPR2 encephalitis was initially associated with Morvan's syndrome. Both entities, however, may have much more complex central and peripheral semiology, including seizures, psychiatric or personality changes, autonomic instability, and peripheral neuropathic symptoms. Thirty-nine percent of patients with anti-LGI1 antibodies will exhibit hyponatremia. As with anti-NMDAR encephalitis, response to immunomodulatory treatment is often excellent, but treatment may need to be prolonged.

\section{Subacute (paraneoplastic) cerebellar degeneration}

Paraneoplastic cerebellar degeneration is characterized by remorselessly progressive signs of cerebellar injury, including central and appendicular ataxia, vertigo, and nystagmus. As the disease progresses, the severity of cerebellar deficits is often well beyond that of most other cerebellar syndromes, leaving the individual unable to sit, stand, or even speak ${ }^{51}$. MRI brain in these patients may be initially normal but later may demonstrate cerebellar atrophy ${ }^{52}$. Major associated tumors include gynecological and breast malignancies, small-cell lung cancer, and Hodgkin's disease. Paraneoplastic cerebellar degeneration should be considered as a diagnosis in any adult patient with subacute progressive cerebellar ataxia in the absence of a family history.

Paraneoplastic cerebellar degeneration may be accompanied by any of several well-described antibodies, and the most common include anti-Yo (PCA-1), PCA-2, anti-Hu (ANNA-1) anti-Ri (ANNA-2), and anti-Tr ${ }^{52}$. Rare cases may be associated with antibodies to the metabotropic glutamate receptors, mGluR1 and mGluR2 ${ }^{53,54}$. The antibody is often suggestive of the underlying tumor, with anti-Yo most often associated with breast or gynecological malignancies, anti-Ri associated with breast or lung malignancies, anti-PCA-2 with lung malignancies ${ }^{55-57}$, and anti-Tr and anti-mGluR1 with Hodgkin's disease $\mathrm{e}^{53,58,59}$. Cerebellar symptoms in patients with anti-Ri and anti-Hu antibodies may be accompanied by opsoclonus. With the exception of cases associated with anti-mGluR1 and possibly those associated with anti-Ri, the course of disease is characterized by progressive, irreversible neuronal loss, making early treatment of great importance and limiting response to immunotherapy as the disease progresses ${ }^{60}$. 


\section{Paraneoplastic encephalomyelitis}

Encephalomyelitis refers to inflammation of the brain or spinal cord (or both) and may present with cortical, brain stem, or spinal involvement either in isolation or concomitantly. Discussed below are specific presentations that clinicians should be aware of while remaining cognizant that one or more may be present at the same time. Anti-NMDAR encephalitis is discussed above.

Limbic encephalitis. Encephalitis involving primarily the limbic system is characterized by a constellation of symptoms and signs that may include personality changes, irritability, depression, seizures, memory loss, and sometimes dementia ${ }^{47,61}$. Limbic encephalitis has been associated with many different antineuronal antibodies. Anti-Hu and anti-Ma2 antibodies have well-described associations with small-cell lung cancer and testicular germ cell tumors, respectively ${ }^{62,63}$. Anti-mGluR5 antibodies may be associated with limbic encephalitis in Hodgkin's disease ${ }^{58}$. Anti-GABAbR and anti-AMPAR antibodies are most commonly associated with small-cell lung cancer and breast cancer or thymoma, respectively ${ }^{64,65}$. Other antibodies that may be associated with limbic encephalitis include those to amphiphysin, Caspr2, LGI1, and GAD65: these may have associated malignancies but, except in cases where antibodies to Caspr2 and LGI1 are present together, more frequently occur in the absence of malignant disease $\mathrm{e}^{66-71}$.

Brain-stem encephalitis. Brain-stem involvement in paraneoplastic disease may present with varying phenotypes, depending on the region of the brain stem that is involved. Gaze palsies present in midbrain involvement, facial palsy or vertical gaze palsies present in pontine involvement, dysarthria or dysphagia or central hypoventilation present in medullary involvement have been documented; patients may also have pyramidal symptoms and gait impairment ${ }^{62,72}$. Anti-Hu and Ma2, associated most commonly with small-cell lung cancer and testicular tumors, respectively, should be strongly considered. Immunotherapy may stabilize symptoms to some degree; however, improvement is often limited, emphasizing the importance of early diagnosis and treatment ${ }^{62,72,73}$. One peculiar syndrome is opsoclonus myoclonus syndrome, which is characterized by rapid and jerking eye movements that are accompanied by myoclonic movements of the extremities and ataxia ${ }^{74}$. Serologically, anti-Hu and anti-Ri antibodies are most commonly associated with this syndrome in adults ${ }^{75,76}$. In children, neuroblastoma is the most frequently associated malignancy ${ }^{77}$. Recently, Kelch-like protein 11 antibodies were identified in patients with brain-stem and cerebellar symptoms and associated testicular seminomas ${ }^{78}$.

Myelitis. Paraneoplastic myelitis should be considered in patients presenting with subacute myelopathy. Presenting symptoms may be non-specific and consistent with myelitis, including flaccid or spastic paraparesis or tetraparesis, urinary or bowel dysfunction, or sensory loss. Rarely, cancer may be accompanied by involvement of spinal cord motor neurons to produce a syndrome suggestive of amyotrophic lateral sclerosis $^{79}$. Paraneoplastic myelitis most commonly occurs in patients with underlying small-cell lung or breast neoplasms. CSF analysis may demonstrate pleocytosis, elevated protein, or the presence of oligoclonal bands with imaging classically demonstrating longitudinally tract-specific enhancement but can be normal in some patients ${ }^{80}$. Paraneoplastic myelitis is most frequently associated with anti-Hu antibodies, and fewer cases are associated with anti-Ri or anti-CRMP5 ${ }^{79,81-83}$. Necrotizing myelitis has also been described; it has a more fulminant presentation, which can occur without associated paraneoplastic antibodies $^{84}$.

\section{Dorsal sensory neuropathy}

Dorsal root ganglionopathies typically present with subacute, asymmetrical, often painful progressive sensory loss usually affecting proprioception and vibratory sensation in comparison with temperature and discriminatory touch ${ }^{85}$. There may also be an association with additional autonomic, cerebral, or cerebellar symptoms $^{86}$. CSF analysis often demonstrates pleocytosis or the presence of oligoclonal bands, and nerve conduction studies are particularly helpful in localizing involvement in the dorsal root ganglia rather than peripheral nerves ${ }^{87,88}$. Dorsal sensory neuronopathy may occur in the setting of small-cell lung cancer, and patients will often have anti-Hu antibodies ${ }^{89,90}$. Dorsal sensory neuronopathy may also occur in non-cancerous disorders such as Sjögren syndrome ${ }^{89}$.

\section{Evaluation and diagnosis}

The clinical presentation of paraneoplastic neurological disease varies widely and often requires a high degree of clinical suspicion in order not to miss the diagnosis. Although the onset of symptoms can be very rapid, most patients develop symptoms in a subacute manner over weeks or sometimes months. Patients may have coexisting autoimmune disease, a family history of autoimmunity or cancer, or risk factors for malignancy. CSF evaluation is essential in these patients. In many patients, CSF analysis may demonstrate pleocytosis, elevated protein, or the presence of oligoclonal bands or a combination of these. In some patients, however, normal CSF does not exclude the possibility of paraneoplastic neurological injury ${ }^{91}$. As the clinical presentation of a specific antibody can vary widely, our recommendation is to test with antibody panels, which are commercially available, rather than single-antibody testing ${ }^{92}$. There is frequently a time lag before results of antibody testing become available. For this reason, prompt empiric therapy should be considered, especially in patients with rapidly worsening syndromes.

In patients with suspected paraneoplastic neurological disease, screening for underlying malignancy is mandatory. Positron emission tomography (PET) is more sensitive to smaller tumors than computed tomography. Antineuronal antibodies may act as markers for specific tumors such as breast or reproductive organ tumors for anti-Yo, small-cell lung cancer for anti-Hu, breast or lung for anti-Ri, or testicle for anti-Ma2. Additional testing, including mammography and pelvic or testicular ultrasound, may be necessary. If malignancy is identified with imaging, treatment should be guided with the aid on an oncologist. Guidelines for diagnosis and tumor search are available ${ }^{93}$. 


\section{Treatment}

Prompt initiation of treatment in paraneoplastic diseaseespecially where the condition is accompanied by antibodies to intracellular antigens-is essential to prevent substantial permanent neurological impairment or death. As testing may take several days to return, we recommend empiric treatment while awaiting results in patients who are highly suspicious for paraneoplastic disease. Subacute onset, focal neurological deficits, abnormal $\mathrm{T} 2$ hyperintensity in the temporal lobes on MRI, and inflammatory CSF are suggestive of an underlying antibody-mediated etiology and should prompt the provider to consider immunotherapy ${ }^{94}$. Although there are no controlled trials to date to guide therapy decisions in paraneoplastic disease, many therapeutic approaches have been employed. Treatment is thus empiric and should be based on the severity of the underlying pathological antibody, the patient's condition, co-morbid medical conditions, and response to immunotherapy.

Treatment of paraneoplastic neurological syndromes begins with therapies addressing the underlying malignancy if one is known or attempts to identify and treat a malignancy not yet detected. Response to treatment of the neurological disorder differs between syndromes associated with antibodies to cell membrane antigens, such as anti-NMDAR encephalitis, and syndromes associated with antibodies reactive with intracellular antigens, such as anti-Yo or anti-Hu. Paraneoplastic neurological syndromes associated with antibodies to cell membrane antigens, such as anti-NMDAR, frequently exhibit a good response to treatment. Intravenous methylprednisolone, usually given as $1000 \mathrm{mg}$ daily for 3 to 5 days, is often used as first-line therapy ${ }^{95}$. Methylprednisolone is often combined or with or followed by treatment with plasma exchange or IVIG or both. Plasma exchange may be carried out using exchanges on an every-other-day basis for a total of five to seven sessions ${ }^{96}$. IVIG is typically dosed at $2 \mathrm{~g} / \mathrm{kg}$ over three to five days ${ }^{97}$. Clinicians should be aware that performing plasmapheresis following IVIG administration will remove the therapeutic IgG just administered. For this reason, plasma exchange should always be performed prior to IVIG. Patients failing these modalities should be considered for treatment with rituximab, typically administered as $1000 \mathrm{mg}$ intravenously for two doses 14 days apart followed by every-six-months dosing, or cyclophosphamide, typically dosed 500 to $1000 \mathrm{mg} / \mathrm{m}^{2}$ every month $^{98,99}$. Also crucial to the long-term treatment in these patients are the identification and treatment of their underlying malignancy ${ }^{100}$.

Treatment of paraneoplastic neurological disease involving antibodies against intracellular antigens such as anti-Hu, anti-Yo, and anti-Ri tends to be more difficult. Corticosteroids, plasma exchange, IVIG, rituximab, and cyclophosphamide have all been used with varying - and usually poor-degrees of success ${ }^{13}$. In these conditions, irreversible neuronal loss occurs over time, making prompt or even urgent treatment extremely important. Evidence suggests that patients may have a better prognosis with earlier initiation of treatment, and pathological studies clearly demonstrate that neuronal loss occurs over time ${ }^{101,102}$. Although treatment may induce only partial remission of neurological symptoms, prompt initiation of therapy may still allow significant functional improvement ${ }^{13,103,104}$. Similar to syndromes associated with antibodies against neuronal membranes, intravenous methylprednisolone is often used as initial treatment, with consideration of concomitant treatment with IVIG in more severe cases Plasmapheresis is a reasonable strategy to consider, although the paraneoplastic antibody may not be removed from the CNS and patients often do not respond to treatment ${ }^{13}$. Both cyclophosphamide and rituximab have been used with some benefit in paraneoplastic disorders, although neither treatment has demonstrated consistent response or decreasing titers of antibody $y^{13,60,105,106}$. One difficulty in determining the effect of different treatment modalities in these conditions is that, in most reports, therapy has been instituted late in the disease course, at a time when neuronal injury and death are already extensive. Importantly, treatment of the underlying tumor is imperative to preventing additional progression of the neurological syndrome associated with the paraneoplastic antibody ${ }^{13,106}$.

Treatment of any paraneoplastic neurological disorder should be closely coordinated with an experienced care team, including an oncologist, neurologist, and surgeon if necessary. Treatment decisions regarding immunotherapy should be agreed upon within the care team, taking into account the timing of necessary radiation or chemotherapy and its effect on timing of immunotherapy. Prompt treatment of the underlying malignancy is important in the overall patient outcome.
1. Furneaux HM, Rosenblum MK, Dalmau J, et al:: Selective expression of Purkinjecell antigens in tumor tissue from patients with paraneoplastic cerebellar degeneration. N Engl J Med. 1990; 322(26): 1844-51. PubMed Abstract | Publisher Full Text

2. Dropcho EJ, Furneaux H, Chen YT, et al.: Expression of the CDR brain protein by tumors from patients with paraneoplastic cerebellar degeneration. Ann Neurol. 1988; 24: 121-2.

3. Manley GT, Smitt PS, Dalmau J, et al:: Hu antigens: Reactivity with hu antibodies, tumor expression, and major immunogenic sites. Ann Neurol. 1995; 38(1): 102-10.

PubMed Abstract | Publisher Full Text
4. $\quad$ F Dalmau J, Tüzün E, Wu HY, et al.: Paraneoplastic anti-N-methyl-D-aspartate receptor encephalitis associated with ovarian teratoma. Ann Neurol. 2007; 61(1): 25-36.

PubMed Abstract | Publisher Full Text | Free Full Text | F1000 Recommendation

5. Wilkinson PC, Zeromski J: Immunofluorescent detection of antibodies against neurones in sensory carcinomatous neuropathy. Brain. 1965; 88(3): 529-83. PubMed Abstract | Publisher Full Text

6. Trotter JL, Hendin BA, Osterland CK: Cerebellar degeneration with Hodgkin disease. An immunological study. Arch Neurol. 1976; 33(9): 660-1. PubMed Abstract | Publisher Full Text 
7. Greenlee JE, Brashear HR: Antibodies to cerebellar Purkinje cells in patients with paraneoplastic cerebellar degeneration and ovarian carcinoma. Ann Neurol. 1983; 14(6): 609-13.

PubMed Abstract | Publisher Full Text

8. Jaeckle KA, Graus F, Houghton A, et al:: Autoimmune response of patients with paraneoplastic cerebellar degeneration to a Purkinje cell cytoplasmic protein antigen. Ann Neurol. 1985; 18(5): 592-600.

PubMed Abstract | Publisher Full Text

9. F Raspotnig M, Haugen M, Thorsteinsdottir M, et al.: Cerebellar degenerationrelated proteins 2 and 2-like are present in ovarian cancer in patients with and without Yo antibodies. Cancer Immunol Immunother. 2017; 66(11): 1463-71. PubMed Abstract | Publisher Full Text | F1000 Recommendation

10. Darnell JC, Albert ML, Darnell RB: Cdr2, a target antigen of naturally occuring human tumor immunity, is widely expressed in gynecological tumors. Cancer Res. 2000; 60(8): 2136-9.

PubMed Abstract

11. F Small M, Treilleux I, Couillault C, et al:: Genetic alterations and tumor immune attack in Yo paraneoplastic cerebellar degeneration. Acta Neuropathol. 2018; 135(4): 569-79.

PubMed Abstract | Publisher Full Text | F1000 Recommendation

12. F Vialatte de Pémille C, Berzero G, Small M, et al:: Transcriptomic immune profiling of ovarian cancers in paraneoplastic cerebellar degeneration associated with anti-Yo antibodies. Br J Cancer. 2018; 119(1): 105-13. PubMed Abstract | Publisher Full Text | Free Full Text | F1000 Recommendation

13. Greenlee JE: Treatment of paraneoplastic neurologic disorders. Curr Treat Options Neurol. 2010; 12(3): 212-30. PubMed Abstract | Publisher Full Text

14. F Chefdeville A, Treilleux I, Mayeur ME, et al.: Immunopathological characterization of ovarian teratomas associated with anti-N-methyl-Daspartate receptor encephalitis. Acta Neuropathol Commun. 2019; 7(1): 38 PubMed Abstract | Publisher Full Text | Free Full Text | F1000 Recommendation

15. Manto M, Dalmau J, Didelot A, et al:: In vivo effects of antibodies from patients with anti-NMDA receptor encephalitis: Further evidence of synaptic glutamatergic dysfunction. Orphanet J Rare Dis. 2010; 5: 31. PubMed Abstract | Publisher Full Text | Free Full Text

16. F Planagumà J, Leypoldt F, Mannara F, et al:: Human N-methyl D-aspartate receptor antibodies alter memory and behaviour in mice. Brain. 2015; 138(Pt 1): 94-109.

PubMed Abstract | Publisher Full Text | Free Full Text | F1000 Recommendation

17. F Hughes EG, Peng X, Gleichman AJ, et al.: Cellular and Synaptic Mechanisms of Anti-NMDA Receptor Encephalitis. J Neurosci. 2010; 30(17): 5866-75. PubMed Abstract | Publisher Full Text | Free Full Text | F1000 Recommendation

18. Lai M, Hughes EG, Peng $X$, et al:: AMPA receptor antibodies in limbic encephalitis alter synaptic receptor location. Ann Neurol. 2009; 65(4): 424-34. PubMed Abstract | Publisher Full Text | Free Full Text

19. F Nibber A, Mann EO, Pettingill $P$, et al:: Pathogenic potential of antibodies to the GABAB receptor. Epilepsia Open. 2017; 2(3): 355-9.

PubMed Abstract | Publisher Full Text | Free Full Text | F1000 Recommendation

20. Peng $\mathrm{X}$, Hughes $\mathrm{EG}$, Moscato $\mathrm{EH}$, et al.: Cellular plasticity induced by antia-amino-3-hydroxy-5-methyl-4-isoxazolepropionic acid (AMPA) receptor encephalitis antibodies. Ann Neurol. 2015; 77(3): 381-98. PubMed Abstract | Publisher Full Text | Free Full Text

21. Dalmau J: NMDA receptor encephalitis and other antibody-mediated disorders of the synapse: The 2016 Cotzias Lecture. Neurology. 2016; 87(23): 2471-82. PubMed Abstract | Publisher Full Text | Free Full Text

22. Tanaka K, Tanaka M, Igarashi S, et al:: Trial to establish an animal model of paraneoplastic cerebellar degeneration with anti-Yo antibody. 2. Passive transfer of murine mononuclear cells activated with recombinant Yo protein to paraneoplastic cerebellar degeneration lymphocytes in severe combined immunodeficiency mice. Clin Neurol Neurosurg. 1995; 97(1): 101-5. PubMed Abstract | Publisher Full Text

23. Graus F, Illa I, Agusti M, et al.: Effect of intraventricular injection of an antiPurkinje cell antibody (anti-Yo) in a guinea pig model. J Neurol Sci. 1991; 106(1): 82-7.

PubMed Abstract | Publisher Full Text

24. Sillevis Smitt PA, Manley GT, Posner JB: Immunization with the paraneoplastic encephalomyelitis antigen HuD does not cause neurologic disease in mice. Neurology 1995: 45(10): 1873-8.

PubMed Abstract | Publisher Full Text

25. Sakai K, Gofuku M, Kitagawa $Y$, et al.: Induction of anti-Purkinje cell antibodies in vivo by immunizing with a recombinant 52-kDa paraneoplastic cerebellar degeneration-associated protein. J Neuroimmunol. 1995; 60(1-2): 135-41. PubMed Abstract | Publisher Full Text

26. Voltz R, Dalmau J, Posner JB, et al:: T-cell receptor analysis in anti-Hu associated paraneoplastic encephalomyelitis. Neurology. 1998; 51(4): 1146-50. PubMed Abstract | Publisher Full Text

27. Albert ML, Austin LM, Darnell RB: Detection and treatment of activated T cells in the cerebrospinal fluid of patients with paraneoplastic cerebellar degeneration. Ann Neurol. 2000; 47(1): 9-17. PubMed Abstract | Publisher Full Text

28. Pellkofer HL, Voltz R, Goebels N, et al.: Cross-reactive T-cell receptors in tumor and paraneoplastic target tissue. Arch Neurol. 2009; 66(5): 655-8. PubMed Abstract | Publisher Full Text

29. de Jongste AHC, de Graaf MT, Martinuzzi E, et al: Three sensitive assays do not provide evidence for circulating HuD-specific T cells in the blood of patients with paraneoplastic neurological syndromes with anti-Hu antibodies. Neuro Oncol. 2012; 14(7): 841-8.

PubMed Abstract | Publisher Full Text | Free Full Text

30. de Beukelaar JW, Milikan JC, Verjans GM, et al: No evidence for the presence of HuD-specific T cells in the cerebrospinal fluid of patients with Hu-associated paraneoplastic neurological syndromes. J Neurol. 2009; 256(2): 279-82. PubMed Abstract | Publisher Full Text

31. de Beukelaar JW, Verjans GM, van Norden $Y$, et al:: No evidence for circulating HuD-specific CD8+ T cells in patients with paraneoplastic neurological syndromes and Hu antibodies. Cancer Immunol Immunother. 2007; 56(9): 1501-6. PubMed Abstract | Publisher Full Text | Free Full Text

32. F Pellkofer H, Schubart AS, Höftberger R, et al.: Modelling paraneoplastic CNS disease: T-cells specific for the onconeuronal antigen PNMA1 mediat autoimmune encephalomyelitis in the rat. Brain. 2004; 127(Pt 8): 1822-30. PublMed Abstract | Publisher Full Text | F1000 Recommendation

33. Fabian RH, Petroff $\mathrm{G}$ : Intraneuronal IgG in the central nervous system: Uptake by retrograde axonal transport. Neurology. 1987; 37(11): 1780. PubMed Abstract | Publisher Full Text

34. Griffin D, Levine B, Tyor W, et al:: The role of antibody in recovery from alphavirus encephalitis. Immunol Rev. 1997; 159: 155-61. PubMed Abstract | Publisher Full Text

35. Greenlee JE, Burns JB, Rose JW, et al:: Uptake of systemically administered human anticerebellar antibody by rat Purkinje cells following blood-brain barrier disruption. Acta Neuropathol. 1995; 89(4): 341-5.

PubMed Abstract | Publisher Full Text

36. Greenlee JE, Clawson SA, Hill KE, et al.: Anti-Yo Antibody Uptake and Interaction with Its Intracellular Target Antigen Causes Purkinje Cell Death in Rat Cerebellar Slice Cultures: A Possible Mechanism for Paraneoplastic Cerebellar Degeneration in Humans with Gynecological or Breast Cancers. PLoS One. 2015; 10(4): e0123446.

PubMed Abstract | Publisher Full Text | Free Full Text

37. Greenlee JE, Clawson SA, Hill KE, et al:: Purkinje cell death after uptake of anti-Yo antibodies in cerebellar slice cultures. J Neuropathol Exp Neurol. 2010; 69(10): 997-1007

PubMed Abstract | Publisher Full Text | Free Full Text

38. Panja D, Vedeler CA, Schubert M: Paraneoplastic cerebellar degeneration: Yo antibody alters mitochondrial calcium buffering capacity. Neuropathol Appl Neurobiol. 2019; 45(2): 141-156.

PubMed Abstract | Publisher Full Text

39. Schubert M, Panja D, Haugen M, et al:: Paraneoplastic CDR2 and CDR2L antibodies affect Purkinje cell calcium homeostasis. Acta Neuropathol. 2014; 128(6): 835-52.

PubMed Abstract | Publisher Full Text | Free Full Text

40. Greenlee JE, Parks TN, Jaeckle KA: Type lla ('anti-Hu') antineuronal antibodies produce destruction of rat cerebellar granule neurons in vitro. Neurology. 1993; 43(10): 2049.

PubMed Abstract | Publisher Full Text

41. Greenlee JE, Clawson SA, Hill KE, et al.: Neuronal uptake of anti-Hu antibody, but not anti-Ri antibody, leads to cell death in brain slice cultures. J Neuroinflammation. 2014; 11: 160. PubMed Abstract | Publisher Full Text | Free Full Text

42. F Armangue T, Spatola M, Vlagea A, et al:: Frequency, symptoms, risk factors, and outcomes of autoimmune encephalitis after herpes simplex encephalitis: a prospective observational study and retrospective analysis. Lancet Neurol. 2018; 17(9): 760-72.

PubMed Abstract | Publisher Full Text | Free Full Text | F1000 Recommendation

43. F Gable MS, Sheriff $\mathrm{H}$, Dalmau J, et al:: The frequency of autoimmune N-methyl$\mathrm{D}$-aspartate receptor encephalitis surpasses that of individual viral etiologies in young individuals enrolled in the California Encephalitis Project. Clin Infect Dis. 2012; 54(7): 899-904

PubMed Abstract | Publisher Full Text | Free Full Text | F1000 Recommendation

44. F Dalmau J, Lancaster E, Martinez-Hernandez E, et al.: Clinical experience and laboratory investigations in patients with anti-NMDAR encephalitis. Lancet Neurol. 2011; 10(1): 63-74.

PubMed Abstract | Publisher Full Text | Free Full Text | F1000 Recommendation

45. Johnson N, Henry C, Fessler AJ, et al:: Anti-NMDA receptor encephalitis causing prolonged nonconvulsive status epilepticus. Neurology. 2010; 75(16): 1480-2. PubMed Abstract | Publisher Full Text | Free Full Text

46. Titulaer MJ, Dalmau J: Seizures as first symptom of anti-NMDA receptor encephalitis are more common in men. Neurology. 2014; 82(7): 550-1. PubMed Abstract | Publisher Full Text

47. Tüzün $E$, Dalmau J: Limbic encephalitis and variants: classification, diagnosis and treatment. Neurologist. 2007; 13(5): 261-71.

PubMed Abstract | Publisher Full Text

48. da Rocha AJ, Nunes RH, Maia AC Jr, et al:: Recognizing Autoimmune-Mediated Encephalitis in the Differential Diagnosis of Limbic Disorders. AJNR Am J Neuroradiol. 2015; 36(12): 2196-205.

PubMed Abstract | Publisher Full Text 
49. Pessa ME, Janes F, Gigli GL: Electroencephalographic Evaluation for Early Diagnosis of Limbic Encephalitis. Clin EEG Neurosci. 2016; 47(3): 207-10. PubMed Abstract | Publisher Full Text

50. F Gadoth A, Pittock SJ, Dubey D, et al.: Expanded phenotypes and outcomes among 256 LGI1/CASPR2-IgG-positive patients. Ann Neurol. 2017; 82(1): 79-92. PubMed Abstract | Publisher Full Text | F1000 Recommendation

51. Brain L, Wilkinson M: Subacute cerebellar degeneration associated with neoplasms. Brain. 1965; 88(3): 465-78.

PubMed Abstract | Publisher Full Text

52. Vernino S: Paraneoplastic cerebellar degeneration. Handb Clin Neurol. 2012 103: 215-23.

Publisher Full Text

53. Sillevis Smitt P, Kinoshita A, de Leeuw B, et al:: Paraneoplastic cerebellar ataxia due to autoantibodies against a glutamate receptor. N Engl J Med. 2000; 342(1): $21-7$.

PubMed Abstract | Publisher Full Text

54. F Ruiz-García R, Martínez-Hernández E, Joubert B, et al:: Paraneoplastic cerebellar ataxia and antibodies to metabotropic glutamate receptor 2. Neurol Neuroimmunol Neuroinflamm. 2019; 7(2): pii: e658.

PubMed Abstract | Publisher Full Text | Free Full Text | F1000 Recommendation

55. Venkatraman A, Opal P: Paraneoplastic cerebellar degeneration with anti-Yo antibodies - a review. Ann Clin Transl Neurol. 2016; 3(8): 655-63. PubMed Abstract | Publisher Full Text | Free Full Text

56. Pittock SJ, Lucchinetti CF, Lennon VA: Anti-neuronal nuclear autoantibody type 2: Paraneoplastic accompaniments. Ann Neurol. 2003; 53(5): 580-7. PubMed Abstract | Publisher Full Text

57. Vernino S, Lennon VA: New Purkinje cell antibody (PCA-2): Marker of lung cancer-related neurological autoimmunity. Ann Neurol. 2000; 47(3): 297-305. PubMed Abstract | Publisher Full Text

58. Lancaster E, Martinez-Hernandez E, Titulaer MJ, et al:: Antibodies to metabotropic glutamate receptor 5 in the Ophelia syndrome. Neurology. 2011; 77(18): 1698-701. PubMed Abstract | Publisher Full Text | Free Full Text

59. Bernal F, Shams'ili S, Rojas I, et al:: Anti-Tr antibodies as markers of paraneoplastic cerebellar degeneration and Hodgkin's disease. Neurology. 2003; 60(2): 230-4

PubMed Abstract | Publisher Full Text

60. Keime-Guibert F, Graus F, Fleury A, et al:: Treatment of paraneoplastic neurological syndromes with antineuronal antibodies (Anti-Hu, AntiYo) with a combination of immunoglobulins, cyclophosphamide, and methylprednisolone. J Neurol Neurosurg Psychiatry. 2000; 68(4): 479-82. PubMed Abstract | Publisher Full Text | Free Full Text

61. Gultekin SH, Rosenfeld MR, Voltz R, et al:: Paraneoplastic limbic encephalitis: Neurological symptoms, immunological findings and tumour association in $\mathbf{5 0}$ patients. Brain. 2000; 123(Pt 7): 1481-94

PubMed Abstract | Publisher Full Text

62. Dalmau J, Graus F, Villarejo A, et al:: Clinical analysis of anti-Ma2-associated encephalitis. Brain. 2004; 127(Pt 8): 1831-44. PubMed Abstract | Publisher Full Text

63. Greenlee JE, Boyden JW, Pingree M, et al.: Antibody types and IgG subclasse in paraneoplastic neurological syndromes. J Neurol Sci. 2001; 184(2): 131-7. PubMed Abstract | Publisher Full Text

64. F van Coevorden-Hameete MH, de Bruijn MAAM, de Graaff E, et al.: The expanded clinical spectrum of anti-GABABR encephalitis and added value of KCTD16 autoantibodies. Brain. 2019; 142(6): 1631-43. PubMed Abstract | Publisher Full Text | Free Full Text | F1000 Recommendation

65. Höftberger R, van Sonderen A, Leypoldt F, et al:: Encephalitis and AMPA receptor antibodies: Novel findings in a case series of 22 patients. Neurology. 2015; 84(24): 2403-12

PubMed Abstract | Publisher Full Text | Free Full Text

66. Irani SR, Vincent A: Voltage-gated potassium channel-complex autoimmunity and associated clinical syndromes. Handb Clin Neurol. 2016; 133: 185-97. PubMed Abstract | Publisher Full Text

67. F McKeon A, Tracy JA: GAD65 neurological autoimmunity. Muscle Nerve. 2017; 56(1): 15-27.

PubMed Abstract | Publisher Full Text | F1000 Recommendation

68. Bataller L, Galiano R, García-Escrig M, et al:: Reversible paraneoplastic limbic encephalitis associated with antibodies to the AMPA receptor. Neurology. 2010; 74(3): 265-7.

PubMed Abstract | Publisher Full Text | Free Full Text

69. Bataller L, Kleopa KA, Wu GF, et al:: Autoimmune limbic encephalitis in 39 patients: Immunophenotypes and outcomes. J Neurol Neurosurg Psychiatry. 2006; 78(4): 381-5.

PubMed Abstract | Publisher Full Text | Free Full Text

70. Dorresteijn LDA, Kappelle AC, Renier WO, et al: Anti-amphiphysin associated limbic encephalitis: A paraneoplastic presentation of small-cell lung carcinoma. J Neurol. 2002; 249(9): 1307-8.

PubMed Abstract | Publisher Full Text

71. Gagnon MM, Savard M: Limbic Encephalitis Associated With GAD65 Antibodies: Brief Review of the Relevant literature. Can J Neurol Sci. 2016; 43(4): 486-93. PubMed Abstract | Publisher Full Text
72. Saiz A, Bruna J, Stourac P, et al.: Anti-Hu-associated brainstem encephalitis J Neurol Neurosurg Psychiatry. 2009; 80(4): 404-7.

PubMed Abstract | Publisher Full Text

73. Blaes F: Paraneoplastic Brain Stem Encephalitis. Curr Treat Options Neurol. 2013; 15(2): 201-9.

PubMed Abstract | Publisher Full Text

74. Desai J, Mitchell WG: Acute cerebellar ataxia, acute cerebellitis, and opsoclonus-myoclonus syndrome. J Child Neurol. 2012; 27(11): 1482-8. PubMed Abstract | Publisher Full Text

75. Armangué T, Sabater L, Torres-Vega E, et al.: Clinical and Immunological Features of Opsoclonus-Myoclonus Syndrome in the Era of Neuronal Cell Surface Antibodies. JAMA Neurol. 2016; 73(4): 417-24. PubMed Abstract | Publisher Full Text | Free Full Text

76. Bataller L, Graus F, Saiz A, et al:: Clinical outcome in adult onset idiopathic or paraneoplastic opsoclonus-myoclonus. Brain. 2001; 124(Pt 2): 437-43. PubMed Abstract | Publisher Full Text

77. Blaes F, Pike MG, Lang B: Autoantibodies in childhood opsoclonus-myoclonus syndrome. J Neuroimmunol. 2008; 201-202: 221-6.

PubMed Abstract | Publisher Full Text

78. F Mandel-Brehm C, Dubey D, Kryzer TJ, et al:: Kelch-like Protein 11 Antibodies in Seminoma-Associated Paraneoplastic Encephalitis. N Engl J Med. 2019; 381(1): 47-54

PubMed Abstract | Publisher Full Text | Free Full Text | F1000 Recommendation

79. Forsyth PA, Dalmau J, Graus F, et al:: Motor neuron syndromes in cancer patients. Ann Neurol. 1997; 41(6): 722-30.

PubMed Abstract | Publisher Full Text

80. Flanagan EP, McKeon A, Lennon VA, et al:: Paraneoplastic isolated myelopathy: Clinical course and neuroimaging clues. Neurology. 2011; 76(24): 2089-95. PubMed Abstract | Publisher Full Text

81. F Dericioglu N, Gocmen R, Tan E: Paraneoplastic striatal encephalitis and myelitis associated with anti-CV2/CRMP-5 antibodies in a patient with small cell lung cancer. Clin Neurol Neurosurg. 2018; 170: 117-9. PubMed Abstract | Publisher Full Text | F1000 Recommendation

82. Leypoldt F, Eichhorn P, Saager C, et al:: Successful immunosuppressive treatment and long-term follow-up of anti-Ri-associated paraneoplastic myelitis. J Neurol Neurosurg Psychiatry. 2006; 77(10): 1199-200. PubMed Abstract | Publisher Full Text | Free Full Text

83. Flanagan EP, Keegan BM: Paraneoplastic myelopathy. Neurol Clin. 2013; 31(1): 307-18.

PubMed Abstract | Publisher Full Text

84. Rudnicki SA, Dalmau J: Paraneoplastic syndromes of the spinal cord, nerve, and muscle. Muscle Nerve. 2000; 23(12): 1800-18. PubMed Abstract | Publisher Full Text

85. Chalk CH, Windebank AJ, Kimmel DW, et al:: The Distinctive Clinical Features of Paraneoplastic Sensory Neuronopathy. Can J Neurol Sci. 1992; 19(3): 346-51. PubMed Abstract

86. Dalmau J, Graus F, Rosenblum MK, et al:: Anti-Hu--associated paraneoplastic encephalomyelitis/sensory neuronopathy. A clinical study of 71 patients. Medicine (Baltimore). 1992; 71(2): 59-72. PubMed Abstract | Publisher Full Text

87. Camdessanché JP, Antoine JC, Honnorat J, et al.: Paraneoplastic peripheral neuropathy associated with anti-Hu antibodies. A clinical and electrophysiological study of 20 patients. Brain. 2002; 125(Pt 1): 166-75. PubMed Abstract | Publisher Full Text

88. Lauria G, Pareyson D, Sghirlanzoni A: Neurophysiological diagnosis of acquired sensory ganglionopathies. Eur Neurol. 2003; 50(3): 146-52. PubMed Abstract | Publisher Full Text

89. Gwathmey KG: Sensory neuronopathies. Muscle Nerve. 2016; 53(1): 8-19. PubMed Abstract | Publisher Full Text

90. Graus F, Keime-Guibert F, Reñe R, et al:: Anti-Hu-associated paraneoplastic encephalomyelitis: analysis of 200 patients. Brain. 2001; 124(Pt 6): 1138-48. PubMed Abstract | Publisher Full Text

91. F Dubey D, Pittock SJ, Kelly CR, et al:: Autoimmune encephalitis epidemiology and a comparison to infectious encephalitis. Ann Neurol. 2018; 83(1): 166-77. PubMed Abstract | Publisher Full Text | Free Full Text | F1000 Recommendation

92. Dalmau J, Geis C, Graus F: Autoantibodies to Synaptic Receptors and Neuronal Cell Surface Proteins in Autoimmune Diseases of the Central Nervous System. Physiol Rev. 2017; 97(2): 839-87.

PubMed Abstract | Publisher Full Text | Free Full Text

93. Titulaer MJ, Soffietti R, Dalmau J, et al:: Screening for tumours in paraneoplastic syndromes: report of an EFNS task force. Eur J Neurol. 2011; 18(1): 19-e3. PubMed Abstract | Publisher Full Text | Free Full Text

94. F Graus F, Titulaer MJ, Balu R, et al:: A clinical approach to diagnosis of autoimmune encephalitis. Lancet Neurol. 2016; 15(4): 391-404. PubMed Abstract | Publisher Full Text | Free Full Text | F1000 Recommendation

95. Mann AP, Grebenciucova E, Lukas RV: Anti- $\mathbf{N}$-methyl-D-aspartate-receptor encephalitis: Diagnosis, optimal management, and challenges. Ther Clin Risk Manag. 2014; 10: 517-25.

PubMed Abstract | Publisher Full Text | Free Full Text 
96.

Cortese I, Cornblath DR: Therapeutic plasma exchange in neurology: 2012 J Clin Apher. 2013; 28(1): 16-9.

PubMed Abstract | Publisher Full Text | Free Full Text

97. Widdess-Walsh P, Tavee JO, Schuele S, et al:: Response to intravenous immunoglobulin in anti-Yo associated paraneoplastic cerebellar degeneration: case report and review of the literature. J Neurooncol. 2003; 63(2): 187-90. PubMed Abstract | Publisher Full Text

98. F Lee WJ, Lee ST, Byun Jl, et al:: Rituximab treatment for autoimmune limbic encephalitis in an institutional cohort. Neurology. 2016; 86(18): 1683-91. PubMed Abstract | Publisher Full Text | F1000 Recommendation

99. Thöne J, Hohaus A, Lamprecht S, et al.: Effective immunosuppressant therapy with cyclophosphamide and corticosteroids in paraneoplastic cerebellar degeneration. J Neurol Sci. 2008; 272(1-2): 171-3.

PubMed Abstract | Publisher Full Text

100. de Beukelaar JW, Sillevis Smitt PA: Managing paraneoplastic neurological disorders. Oncologist. 2006; 11(3): 292-305. PubMed Abstract | Publisher Full Text

101. Stark E, Wurster U, Patzold U, et al:: Immunological and clinical response to immunosuppressive treatment in paraneoplastic cerebellar degeneration.
Arch Neurol. 1995; 52(8): 814-8.

PubMed Abstract | Publisher Full Text

102. Vernino S, O'Neill BP, Marks RS, et al.: Immunomodulatory treatment trial for paraneoplastic neurological disorders. Neuro-oncology. 2004; 6(1): 55-62. PubMed Abstract | Publisher Full Text | Free Full Text

103. Shams'ili S, Grefkens J, de Leeuw B, et al.: Paraneoplastic cerebellar degeneration associated with antineuronal antibodies: analysis of $\mathbf{5 0}$ patients. Brain. 2003; 126(Pt 6): 1409-18.

PubMed Abstract | Publisher Full Text

104. Graus $\mathrm{F}$, Abos J, Roquer $\mathrm{J}$, et al:: Effect of plasmapheresis on serum and CSF autoantibody levels in CNS paraneoplastic syndromes. Neurology. 1990; 40(10): 1621-3.

PubMed Abstract | Publisher Full Text

105. Esposito M, Penza P, Orefice G, et al.: Successful treatment of paraneoplastic cerebellar degeneration with Rituximab. J Neurooncol. 2008; 86(3): 363-4. PubMed Abstract | Publisher Full Text

106. Vedeler CA, Antoine JC, Giometto B, et al.: Management of paraneoplastic neurological syndromes: report of an EFNS Task Force. Eur J Neurol. 2006 13(7): 682-90.

PubMed Abstract | Publisher Full Text 


\section{Open Peer Review}

\section{Current Peer Review Status:}

\section{Editorial Note on the Review Process}

Faculty Reviews are review articles written by the prestigious Members of Faculty Opinions. The articles are commissioned and peer reviewed before publication to ensure that the final, published version is comprehensive and accessible. The reviewers who approved the final version are listed with their names and affiliations.

\section{The reviewers who approved this article are:}

\section{Version 1}

\section{Jerome Honnorat}

Institut NeuroMyoGene INSERM U1217/CNRS UMR 5310, Université de Lyon, Université Claude Bernard Lyon, Lyon, France

Competing Interests: No competing interests were disclosed.

\section{Francesc Graus}

Neuroimmunology Programme, Institut d'Investigacions Biomèdiques August Pi i Sunyer (IDIBAPS), Hospital Clinic, University of Barcelona, Barcelona, Spain

Competing Interests: No competing interests were disclosed.

The benefits of publishing with F1000Research:

- Your article is published within days, with no editorial bias

- You can publish traditional articles, null/negative results, case reports, data notes and more

- The peer review process is transparent and collaborative

- Your article is indexed in PubMed after passing peer review

- Dedicated customer support at every stage

For pre-submission enquiries, contact research@f1000.com 